\title{
Make in India: A Platform to Indian Handloom Market
}

\author{
Dr. Sabiha Khatoon \\ Post Doctoral Fellow, D/O Commerce, Aligarh Muslim University, Aligarh
}

\begin{abstract}
Make in India- a program designed and initiated by the government of India to promote India as a global manufacturing destination, facilitate investment, foster innovation, and build best-in-class manufacturing infrastructure. This 'Make in India' campaign covering 25 sectors, including the textiles and garments, is going to become a land mark for Indian Textiles Industry. Handloom being a major sub-sector of Indian Textiles Industry plays a pivotal role in Indian economy, providing direct employment to over 65 lakh persons engage in weaving and allied activities. With almost one fourth of the total textile production and contributing substantially to the export earnings, the handloom remains dominant industrial sector in the country. Handloom is unparalleled in its flexibility and versality, permitting experimentation and encouraging innovation. Innovative weavers with their skillful blending of myths, faiths, symbols and imagery provide the fabric an appealing dynamism. But still handloom continues to be a traditional and hereditary occupation, using traditional methods of production and designs due to lack of exposure, awareness and knowledge about changing technologies, methods and the requirements. Therefore, there is a need to make handloom tradition fashionable by introducing new designs and colour schemes, so that it can find a reference place in global textiles industry. Handloom weavers can make it possible by using 'Make in India' as a platform and at the same time can promote themselves and their innovative products not only in India but in global market also.
\end{abstract}

Keywords: Make in India, Indian Handloom sector, textile, weavers, innovation, marketing strategies

\section{Introduction}

Indian handloom sector of the textile industry is ancient and has served the economy well in terms of employment. India is currently the world's largest producer of handloom products with a total production of more than 7116 million sqr. meters in the year 2013-14. Among the products produced in India, the most celebrated ones include Jamdani, Ikkat, Kota, Banarasi and Patola. In the entire country, there are more than 38 lakhs handlooms. In north-eastern States, there are more than 15 lakhs domestic handlooms. Handlooms in north India and South India are geared for commercial production for domestic market and also exporting their products abroad.

Handloom industry is the largest cottage industry in the country. The importance of this sector lies in its size and employment potential. It provides direct and indirect employment to more than 43 lakh weavers and is the largest economic activity second only to agriculture. The relevance of the handloom sector in the agrarian economy is immense because of its linkages with crucial and sensitive sectors like agriculture. It uses agricultural products as raw materials and, therefore, provides an ever-ready market for agricultural produce. Therefore, in an economy where majority of people rely on agrarian sector for their livelihood, the significance of handloom is well understood. It also gives employment to a lot of women and, thus, plays its role in women empowerment.

The strength of this sector is its innovation and dynamism in relating itself to the changing market needs and requirements. Indian textile industry, including spinning, weaving (and knitting), fabric processing and garment-making units, account for about one-fifth of India's total industrial output in 1994-95 and about 7 percent of GDP - share of the handloom sub-sector in fabric output is around 35 percent. This sector also contributes nearly 23 percent of the total cloth produced.

If the importance of the handloom sector is of such colossal character then the question to be asked is why this particular sector is facing so many problems? Handloom weavers today are suffering and are facing a series of problems ranging from unorganised nature of their business to threat from cheap imports. The problems that the weavers tackle have compounded in the recent times. This has led to closure of many handloom units and thus has resulted in considerable unemployment.

\section{Statement of the Problem}

The present study is an attempt to analyse the importance of Indian handloom sector and problems suffered by the sector. The study is expected to reveal the problems that the Indian handloom weavers are facing and importance of 'Make in India' campaign for alleviating Indian handloom sector. 


\section{Scope of the Study}

The present study is integrated and comprehensive study on Indian handloom sector and 'Make in India' campaign projecting its importance for the concerned sector. This study is an attempt to reveal the shortcomings of Indian handloom sector and focuses on the objectives of 'Make in India' campaign that may prove to a platform for the promotion and development of Indian handloom market.

The detailed objectives of the study are:

\section{Objectives of the study}

- To study the present status of Indian handloom industry

- To examine the policy of the Govt. of India towards promoting the handloom industry.

- To study the major challenges of the Handloom Sector of India.

- To analyse the importance of 'Make in India' campaign for the development of Indian handloom market.

Research Type: Descriptive Research

\section{Research Methodology}

Type of Data/ Data Source used: Secondary Data/ Data Source. The present study is based on secondary data. Basically, the required information has been derived from

1. Books, articles from Newspapers, Magazines and Journals, and

2. From various related web-sites which deal directly or indirectly with the topics related to Indian Handloom and Make in India.

\section{Status of Indian Handloom Industry}

As an economic activity, handloom is the one of the largest employment providers after agriculture. The sector provides employment to 43.31 lakh persons engaged on about 23.77 lakh handlooms, of which, 10 percent are from scheduled castes, 18 percent belong to scheduled tribes, 45 percent belong to other backward classes and 27 percent are from other castes. Production in the handloom sector recorded a figure of 6952 million sqr.meters in the year 2012-13. During 2013-14 production in the handloom sector is reported to be 7116 million sqr. meters and details are given under Table 1 . The data given in the table shows an improvement in production of cloth by handloom sector over the years.

Table 1: Cloth Production by Handloom Sector (Mn. Sq. Mtrs)

\begin{tabular}{|l|l|l|l|l|}
\hline Year & $\begin{array}{l}\text { Cloth production } \\
\text { by handloom } \\
\text { sector }\end{array}$ & $\begin{array}{l}\text { Share of handloom } \\
\text { in the total cloth } \\
\text { production }\end{array}$ & $\begin{array}{l}\text { Ratio of handloom } \\
\text { to powerloom (in } \\
\text { terms of cloth) }\end{array}$ & $\begin{array}{l}\text { Total cloth } \\
\text { production } \\
*\end{array}$ \\
\hline $2008-09$ & 6677 & 15.9 & $1: 5.04$ & 42121 \\
\hline $2009-10$ & 6806 & 14.9 & $1: 5.41$ & 45819 \\
\hline $2010-11$ & 6900 & 14.6 & $1: 5.59$ & 47083 \\
\hline $2011-12$ & 6901 & 14.8 & $1: 5.42$ & 46600 \\
\hline $2012-13$ & 6952 & 14.6 & $1: 5.47$ & 47408 \\
\hline $2013-14$ & $7116(\mathrm{P})$ & 15.01 & $1: 5.29$ & 47388 \\
\hline
\end{tabular}

Source: Ministry of Textiles, Govt. of India

Table 2: Handlooms Export Performance in the past few years

The export of handlooms during 2009-10 to 2012-13 and 2013-14 has been as under:

\begin{tabular}{|l|l|l|l|}
\hline Year & Target & Achievement & Handloom Exports in Rupees terms (In Crore) \\
\hline $2009-10$ & NA & 278 & 1252.80 \\
\hline $2010-11$ & 300 & 350 & 1574.95 \\
\hline $2011-12$ & 500 & 535 & 2653.95 \\
\hline $2012-13$ & 400 & 520 & 2811.97 \\
\hline $2013-14$ & 602 & 372 & 2233.11 \\
\hline
\end{tabular}

Source: Office of the Development Commissioner (Handlooms), Ministry of Textiles, Govt. of India.

Harmonized System of Classification for Handlooms products was introduced in 2009-10. Exports of Handlooms during 2009-10 were of the order of Rs. 1252.80 Crore and increased to 1574.95 crore in 2010-11, recording a growth of 25 per cent. During 2011-12, exports of Handloom further increased to Rs.2653.95 Crore, recording a growth of 68 per cent. Exports in this category of items have decreased from Rs.2811.97 Crore in 2012-13 to Rs. 2233.11 Crore in 2013-14, that is, a decline of 20 per cent. This is the most labour intensive sector and its activities mostly support the rural employment. Negative exports performance of this category of items needs to be reversed through active trade policy supports measures. 
The biggest destination of India's Handlooms products is the USA followed by the EU. In 2014-15, the US was the major importer of Indian handloom products, with estimated purchases of US4 107.95 million, followed by the UK and Germany at US\$ 29.7 million, respectively. Italy, France, Japan, Saudi Arabia, Australia, the Netherlands and the UAE were some other export destinations.

\section{Schemes being Implemented in Handloom Sector}

1. National Handloom Development Programme It is a Centrally Sponsored Scheme implemented through State Governments, which comprises the following components related to marketing, infrastructure development and credit availability:

(i) Comprehensive Handloom Development Scheme (Integrated Handloom Development Scheme, Diversified Handloom Development Scheme and Marketing and Export Promotion Scheme): The main objectives of this scheme is to provide financial assistance for cluster development programme, organizing exhibitions, events and craft melas, setting up of Urban Haats, and encourage participation in international fairs. This scheme also put efforts in strengthening and setting up of service centres for weavers and Indian Institution of Handloom Technology and taking initiatives for skill upgardation of weavers.

(ii) Revival, Reform and Restructuring Package (RRR): The objectives of this scheme is to unlock the credit lines of handloom sector by releasing overdues along with interest as on 31.3.2010 and provide the recapitalization assistance to eligible primary weavers cooperative (PWC) societies that they become functional and self sustainable and could access the fresh credit from banks for which Government of India also provided interest subsidy of 3 percent for a period of 3 years and credit guarantee to such loan.

2. Yarn Supply Scheme: This scheme has three components, namely, (I) Supply of yarn at Mill Gate Price (ii) 10 percent Price Subsidy on cotton hank yarn, domestic silk and wool (iii) Investment in NHDC. The objective of this scheme is to make available all types of yarn at Mill Gate Price to the eligible handloom weavers so as to ensure the regular supply of basic raw materials to the handloom sector and help utilize the full employment potectial of the sector

3. Handloom Weavers' Comprehensive Welfare Scheme: Government of India has been implementing this scheme with the following two components:

(i) Health Insurance Scheme (HIS): Government of India introduced this scheme in 2005-06 and implemented in a revised form in 2007-08 and 2008-09. The aim of this scheme is to provide medical cover to weaver and his family of Rs.37,500/- (Rs.7500 for OPD and Rs.30,000 for in-patient treatment (IPT).

(ii) Mahatma Gandhi Bunkar Bima Yojana (MGBBY): Government of India introduced this scheme in December, 2003. the basic objective of this scheme is to provide enhanced insurance cover to the handloom weavers: Rs.60,000 in case of natural death, Rs.1.5 lakh in case of accidental death and Rs.75,000 in cases of total or partial disability.

Table 3: Details showing the financial releases (in crores) during the 12th Plan period are given below:

\begin{tabular}{|c|c|c|c|c|}
\hline Scheme & 2012-13 & 2013-14 & 2014-15 & 2015-16 \\
\hline National Handloom Development Programme & & & 288.00 & 125.00 \\
\hline Comprehensive Handloom Development scheme & & 107.00 & & \\
\hline Integrated Handloom Development Scheme (CSS) & 170.00 & & & \\
\hline $\begin{array}{l}\text { Revival reforms and restructuring package for handlooms } \\
\text { (CSS) }\end{array}$ & $2,205.00$ & 157.00 & & \\
\hline Market and Export Promotion Scheme (CSS) & 48.00 & & & \\
\hline Diversified Handloom Development Scheme & 20.00 & & & \\
\hline Weaver Service centre & 32.50 & 35.00 & 33.00 & 38.00 \\
\hline Handloom Weavers Comprehensive Welfare Scheme & 105.00 & 65.00 & 55.00 & 15.00 \\
\hline Mill Gate Price Scheme & 350.00 & 96.50 & 125.00 & 140.00 \\
\hline $\begin{array}{l}\text { Scheme for grant of special rebate at the rate of ten percent } \\
\text { on sale of accumulated Handloom stock }\end{array}$ & & 0.01 & 0.01 & \\
\hline Trade Facilitation Centre and Crafts Museum & & & & 80.00 \\
\hline Others & 30.00 & 32.99 & 37.50 & 42.00 \\
\hline CHCDS - Handloom Mega Cluster & & 26.00 & 26.00 & 6.60 \\
\hline Lump sum provision for Northeast and Sikkim & & & 57.00 & 40.00 \\
\hline Grand Total & $2,960.50$ & $\mathbf{5 1 9 . 5 0}$ & 621.51 & 486.60 \\
\hline
\end{tabular}

Source: Planning Commission.

Allocations for handloom sector have been fluctuating over the past years. As per the data shown in the table above, a Loan waiver package of Rs.2,205 crores included in the 2012-13 budget. This is a huge scale down from Rs.6,800 crore package. However, implementation levels did not exceed Rs.291 crores. In 2013-14, a paltry Rs. 269.79 crores was allocated and in 2014-15, only Rs. 19 crores has been allocated. Market and 
Export Promotion Scheme was allocated Rs. 40 crores in 2012-13, and the expenditure was Rs. 41 crores. In 2011-12, expenditure was Rs. 53 crores and in 2013-14 and 2014-15 there is no allocation for this scheme. Allocation for Handloom Weavers Comprehensive Welfare Scheme for 2014-15 is Rs. 61 crores, down from Rs. 127.03 crores in 2012-13. Overall, allocations are decreasing in handloom sector which needs government's attention.

\section{Major Challenges of the Handloom Sector}

The Indian handloom industry is facing the serious challenges. These are:

Raw Material Availability: Shortage of yarn is one the major barrier for the development of handloom industry. More over the prices of the yarn has been increasing and as a result the amount of profit of the weavers has been decreasing.

Dyes: Colours and designs are Unique Selling Proposition (USPs) of handloom products and hence availability of dyes and colours is of paramount importance. There have been frequent complaints on the colour fastness and colour matching of handloom products. This is partly due to unavailability of good quality dye in small quantities to individual weavers and partly due to lack of awareness on different kinds of dyes and dyeing processes.

Credit Availability: Inadequate finance and access to loans is the other challenge for the weavers. At present 80 per cent of the weavers work with master weavers including with exporters and, therefore, cannot access credit sources directly. Moreover, the remaining weavers find it difficult to fully meet their credit needs on reasonable terms as they are unable to satisfactorily provide adequate security to banks and other financial institutions.

Market Support and Brand Promotion: Because of lack of finance and inadequate marketing facilities weavers are not able to promote their products.

Design: Design is the forte of Handlooms. Very limited design support is provided under Integrated Handloom Development Scheme and the designs made are not marketed.

Poor Working Conditions: Because of unhealthy working conditions, weavers are not interested in taking up handloom as profession.

\section{Other Constraints:}

$>$ The weavers do not get reasonable prices of their finished products

$>$ There is lack of organizational strength.

$>$ During agriculture season the labours get engaged in agricultural field. As a result, the handloom work faces problems in that period.

$>$ Lack of training facilities.

$>$ Lack of transportation facilities.

$>$ Inadequate welfare measure.

\section{Recommendations for the Development of Handloom Industry to avail the advantages of Make in India Scheme}

1. Investment: Government should invest in skill development programmes so as to skill the weavers and their families. Because of these programmes the weavers will be able to add modern blends to the traditional crafts.

2. Quality Assurance: The quality assessment of yarns, woven fabrics, dyeing, finishing and packaging should be done beautifully. To create a stable space for the handloom products in national and international market quality assurance is a must.

3. Growth in Sale: When good quality products will go into the hands of the consumers, the satisfaction of consumer will result in increase in demand of the goods. Hence the sale will be boosted which in turn will boost the production in handloom industry and hence the Indian handloom market will flourish.

4. Cost Control: Proper training facilities should be provided to handloom weavers. This trained and knowledgeable work force will reduce the chances of defects in production system which will in turn bring the cost of production down.

5. Technology Upgradation: Technology upgradation in handloom is necessary to increase the productivity and to make the production system more efficient. This will attract the Indian and foreign designers and investors towards Indian handloom market.

6. Revival of Traditional Handloom: Indian designers should help local weavers and craftsmen to revive traditional handloom products like gota patti, the craft of appliqué of Rajasthan, Tangail and Jaamdaani cotton woven saris of Bengal, Banarasi Saris, Odisha's Ikkat, a 12th century technique of dyeing and binding patterns into threads before the cloth is weaved, reincarnation of age-old 'Kashmiri Stitch' and 
other handloom products which are worldwide famous. Through 'Make in India' they can promote their innovative products in the world market.

7. Market Facilities: There is a need to create awareness about the features, advantages and demand of handloom products in national and international market and for this different promotional means can be adopted. Through 'Make in India' scheme a regular buyer-seller meet can be arranged so that the weavers get a platform to market their products. Moreover, distribution of handloom products can be done through differentiated distribution channels like through website, tie up with designers to sell handloom products.

\section{Conclusion}

On the basis of the above discussion it can be concluded that the handloom sector despite being the dominant segment of Indian textiles industry is surviving in plight. 'Make in India' scheme is giving a new lease of life to Indian handloom industry. This scheme has opened the doors for Indian handloom market to showcase its beauty, strength \& capabilities in international market. By taking 'Make in India' as a platform, the Indian handloom sector can attract the foreign customers, it will help in increasing the export earnings and minimising current account deficit. Make in India can provide a platform to address the challenges facing this sector today. By encouraging greater private investments, the issue of technology upgradation can be addressed and better marketability of handloom products can be ensured. Attractive tax concessions and credit incentives can also allow the availability of much needed capital in this sector. This 'Make in India' initiative might not only fetch foreign exchange in the country, but help promote Indian culture across the world.

\section{References}

[1] Hank Yarn Notification. (http://handlooms.nic.in/hl_hyp_notofocation.htm).

[2] Jain, R. and Goswami, R. (2014). Strategy for Sustainable Development of Handloom Industry. Global Journal of Finance and Management, 6(2), 93-98.

[3] Kundu, M. (2014). Cotton Handloom Industry Problems and Prospects of Development (A Case Study of Alipurduar Block-II. Indian Journal of Research, 3(1), 82-85.

[4] Mahapatro P. C., "Economics of Cotton Handloom Industry in India, Ashish Publishing House, New Delhi, 1996.

[5] Ministry of Commerce and Industry, Govt. of India

[6] Ministry of Textiles, Govt. of India

[7] Office Of The Development Commissioner (Handlooms), Ministry of Textiles, Govt. of India.

[8] Patil, N.U. (2012). Role of Handloom Industry in India. Shodh, Samiksha aur Mulyankan, An International Journal, 4(39), 1-3.

[9] Planning Commission. http://planningcommission.gov.in

[10] Report of the Working Group on Handlooms for Twelfth Five Year Plan (http://planningcommission.gov.in/aboutus/committee/wrkgrp12/wg_handloom1101.pdf). 